\title{
Over the Mountains and Far Away
}

Studies in Near Eastern history and archaeology

presented to Mirjo Salvini on the occasion of his 80th birthday

\author{
edited by \\ Pavel S. Avetisyan, Roberto Dan \\ and \\ Yervand H. Grekyan
}




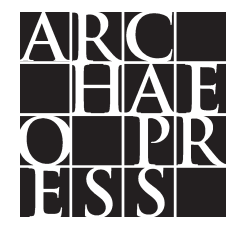

ARCHAEOPRESS PUBLISHING LTD

Summertown Pavilion

18-24 Middle Way

Summertown

Oxford OX2 7LG

www.archaeopress.com

ISBN 978-1-78491-943-6

ISBN 978-1-78491-944-3 (e-Pdf)

(C) Archaeopress and authors 2019

Cover image: Mheri duṛ/Meher kapısı. General view of the 'Gate of Haldi' (9th century BC)
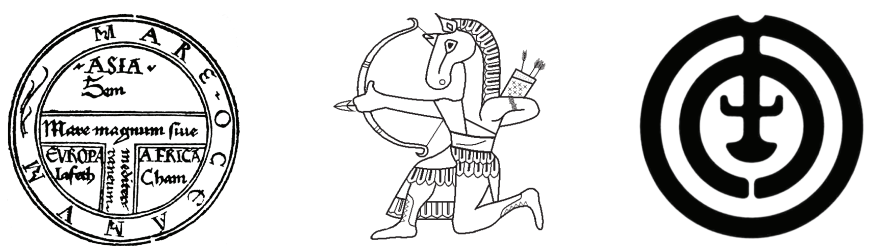

All rights reserved. No part of this book may be reproduced, or transmitted, in any form or by any means, electronic, mechanical, photocopying or otherwise, without the prior written permission of the copyright owners.

Printed in England by Oxuniprint, Oxford.

This book is available direct from Archaeopress or from our website www.archaeopress.com 


\section{Contents}

Editorial. iv

Foreword .. v

Bibliography

Bīsotūn, 'Urartians' and 'Armenians' of the Achaemenid Texts, and the Origins of the Exonyms Armina and Arminiya.. 1 Gregory E. Areshian

Human Images from the Eastern Urartian Periphery: Anthropomorphic Sculpture of Syunik on the Cusp of the 2nd and 1st Millennia BC

Hayk Avetisyan, Artak Gnuni, Gagik Sargsyan and Arsen Bobokhyan

Cult-Places of Ancient Armenia: A Diachronic View and an Attempt of Classification

Pavel Avetisyan and Arsen Bobokhyan

The Elamite Tablets from Armavir-Blur (Armenia): A Re-Examination

Miqayel Badalyan, Gian Pietro Basello and Roberto Dan

Šiuini: The Urartian Sun god

Miqayel Badalyan

Protective Clay Figurines in the Urartian Fortresses

Atilla Batmaz

Mesopotamians and Mesopotamian Learning at Hattusa, Thirty Years On

Gary Beckman

Too Many Horns in the Temple of the God Hadad of Aleppo at the Time of the Ebla Archives!

Maria Giovanna Biga

The Roots of the Urartian Kingdom: The Growth of Social Complexity on the Armenian Plateau Between

Ancient Bronze and Early Iron Ages

Raffaele Biscione

Thoughts about the Audience-Hall of Naramsin at Tell Asmar-Ešnunna

Felix Blocher

The Urartian God Quera and the Metamorphosis of the 'Vishap' Cult

Arsen Bobokhyan, Alessandra Gilibert and Pavol Hnila

Lahmu, 'The Hairy One', and the Puzzling Issue of Mythology in Middle Assyrian Glyptic Art

Dominik Bonatz

The First Gilgamesh Conjectures About the Earliest Epic

Giorgio Buccellati

Ayanis Fortress: Only a Military Fortress or More?

Altan Çilingiroğlu

Granaries in Urartu and Neighboring States and the Monumentalization of Administrative Records

Birgit Christiansen

Hasanlu, the Southern Caucasus and Early Urartu

Megan Cifarelli

The King of the Rock Revisited: The Site of As-Sila (Tafila, Jordan) and the Inscription of Nabonidus of Babylon...... 157 Rocío Da Riva

A New Painting Fragment from Erebuni and an Overview of Urartian Wall Paintings

Roberto Dan, Yeghis Keheyan, Nelli Hovhannisyan, Artur Petrosyan, Yelena Atoyants, Priscilla Vitolo and Boris Gasparyan

New Observations Regarding the Urartian Inscription of the Tul-e Talesh Bracelet

Maryam Dara

Nouvelles réflexions relatives à la fin du royaume d'Ourartou - la forteresse d'Erebuni vers la fin du VIIe

siècle av. J.-C

Stéphane Deschamps, François Fichet de Clairfontaine and Mary Karapetyan

Quand dieu aide les vainqueurs

Jean-Marie Durand 
The Relationship between State and Nomads in the Urartian Kingdom.

Aylin Ü. Erdem

Alcune considerazioni sulla posizione di Uršum e Haššum/Haššuwa: dal commercio paleo-assiro al regno

di Hattušili I.

Massimo Forlanini

L'espressione (ANA) PANI NP nei colofoni ittiti

Rita Francia

From Khazane Kapoussi/Hazine Kapısı to Analıkız: Rethinking a Place at Tušpa Citadel..

Bülent Genç

Some Remarks on Qulha.....

Levan Gordeziani

The Problem of the Origin of the Urartian Scribal School

Yervand Grekyan

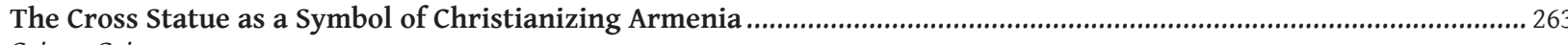

Grigor Grigoryan

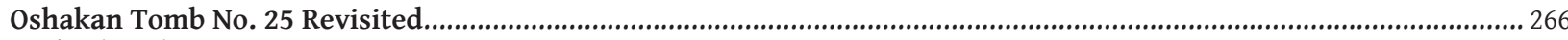

Michael Herles

Urartian Envoys to Ashurbanipal's Court - Some Remarks on the Assyro - Urartian Relations in the First

Half of the 7th Century BC

Krzysztof Hipp

The 'City of Haldi' in the Land of Uaza

Simon Hmayakyan

Urartian Inscriptions at the Van Museum. A New Collection

Kenan Işık

Towards the Reconstruction of the Hurro-Urartian Protolanguage

Margarit Khachikyan

A New Rock-Cut Tomb in Van Fortress/Tushpa

Erkan Konyar

Upper Euphrates Political Geography Reconsidered

Aram Kosyan

The Urartian Rock-Cut Chamber at Yelpin / Armenia.

Stephan Kroll

Le terre di Urartu nella descrizione di Strabone

Gianfranco Maddoli

The Armenian Patronymic Arcruni.

Hrach Martirosyan

Iron Age Luvian tarrawann(i)-

H. Craig Melchert

An Echo of Assyria in Plutarch's Life of Alexander

Sarah C. Melville

Lo strano caso del Sig. VITA+RA/I, scriba ' 4 ' alla corte ittita

Clelia Mora

From Petroglyphs to Alphabet. A Brief Characterization of the Writing Culture of Pre-Christian Armenia

Artak Movsisyan

New Iri-Saĝrig Ration Distribution and Related Texts.

David I. Owen

Le melograne della basilica di Santa Cecilia in Trastevere.

Neda Parmegiani

On the Ethnic Origin of the Ruling Elite of Urartu

Armen Petrosyan

Solak 1. Una fortezza urartea nella valle del Hrazdan, Armenia.

Artur Petrosyan, Roberto Dan and Priscilla Vitolo

Un piccolo frammento di una lunga storia: un cammello a Tell Barri/Kahat (Siria)

Raffaella Pierobon Benoit 
New Ways of Etymologizing Certain Fragments of the Cuneiform Inscription of Tanahat

Ashot Piliposyan

A Note about an Ewer of Probable Anatolian Production, from One of the Tombs of the Assyrian Queens at Nimrud 426 Frances Pinnock

Armenian Toponyms in the 'Patria Quae Dicitur Parthia' according to the Cosmographia of Ravennas Anonymus.... 434 Daniel T. Potts

Updates on Verbal Transitivity and Nominal Ellipsis in Hittite

Jaan Puhvel

The Assyria-Urartu Relationship and the Political Role of Mercenaries

Julian Edgeworth Reade

Zur Frage des Weiterlebens urartäischer Namen in achaimenidischer Zeit

Rüdiger Schmitt

Auf der Suche nach einem Reichsgott für Urartu

Ursula Seidl

Everyday Life in Trialeti (South Caucasus) in the Middle and the Second Half of the 2nd Millennium BC

Nino Shanshashvili and Goderdzi Narimanishvili

A New Fragment of an Inscription of Rusa, Son of Argišti, from the susi Temple of Bastam, Iran.....

Marie-Claude Trémouille, Roberto Dan, Keomars Haji Mohammad and Ebrahim Bodaghi

'Excavating' Looted Tombs at Pessinus (2011-2013).

Gocha R. Tsetskhladze

The Bronze Stamp Seals of Marlik: Evidence of Bronze Age Links with Eastern Iran and Central Asia

Ali A. Vahdati and Amir Saed Mucheshi

Beyt'a Mêzînê A Trace of the Qur'anic Influence on the Yezidi Oral Religious Tradition

Vardan Voskanian

The Ethno-Cultural Diversity of Central Anatolian Early Iron Age Inhabitants

Jak Yakar

The Mighty Weapon of Tarhunt

Ilya Yakubovich

Illiterate Urartians: Writing and the Ayanis Outer Town

Paul Zimansky 


\section{Editorial}

It is hard to quantify the enormous weight of Prof. Mirjo (Miroslavo) Salvini's scientific contribution to Near Eastern studies, and especially to the history, philology and culture of the Urartian civilization. In over 50 years of unceasing research activity, he has contributed in many different fields, but mostly to Urartological studies, helped by his multilingual and multicultural education. Mirjo was inspired to understand Urartu thanks to an intuition of Giovanni Pugliese Carratelli, one of his teachers, who motivated him to take an interest in that distant culture - regarding which, in that period, the first connections were established with Mediterranean cultures, in particular the Greeks and Etruscans. He is one of the few philologists to have understood the necessary relationship between philological data, landscape studies and archaeological knowledge.

This is clearly reflected in his enormous academic production, in which philological information and historical reconstruction are always flanked by the careful and perceptive observation of the archaeological contexts. The desire to know and understand the history and culture of Urartu led him to travel continuously in the areas where Urartu once spread, in Armenia, Turkey, Iran and Iraq. In the 1960s he established direct relations with, among others, Boris Borisovich Piotrovskij (head of Karmirblur excavations), Nikolay Harutyunyan (philologist and Urartologist), Igor' Michajlovič D'jakonov (orientalist and linguist), Konstantin Hovhannisyan (head of Arin-berd excavations), and Afif Erzen (head of Çavuştepe and Toprakkale excavations), visiting the sites and collecting valuable information. He also collaborated with the excavation of Bastam, in northeastern Iran, again studying epigraphic material.

During these travels he was able to discover dozens of unpublished Urartian inscriptions, and very often contributed directly to saving these ancient texts, assisting local institutions, such as the Van Museum, to rescue them. Mirjo has spent almost his entire research career working for the National Research Council in the 'Institute for Mycenaean, Aegean and Anatolian Studies' (ISMEA, 1968-2001), founded by Giovanni Pugliese Carratelli, Piero Meriggi, Carlo Gallavotti and Doro Levi and based on a previous study centre at the University of Rome. Later the name of the institute was changed to 'Institute of Aegean and Near Eastern Studies' (ICEVO, 2001-2013), before being involved in a series of mergers between different CNR institutes that have interrupted the long tradition of studies and research activities. After these events, Mirjo and its collaborators continued the research as members of the ISMEO - International Association of Mediterranean and Oriental Studies. Mirjo directed ISMEA/ ICEVO for a long time contributing in those years to the enlargement of the institute's library, considered at its peak as one of the best in the world for Anatolian and Mycenaean studies. During this period, there were many research activities related to Urartian studies most of which directed by Mirjo. Fundamental among these were the survey and excavations on the western shore of Lake Orumiyeh in Iran that led to the publication in 1984 of the book 'Tra lo Zagros e l'Urmia' co-edited by Mirjo and Paolo Emilio Pecorella, which is still today one of the essential works on that region. During the time of his ICEVO direction important archaeological work was started and continued in Armenia, aimed at studying the borders of the state of Urartu and its impact on local communities in the Lake Sevan area. Also important was his collaboration, and that of the institute, in the excavations of the fortress of Ayanis, on the eastern shore of Lake Van - one of the most important Urartian sites ever excavated, where Mirjo was for a period vice-director and responsible for the study of inscriptions.

However, there is no doubt that his main contribution to Urartological studies was his 'Corpus of Urartian Texts' (CTU), the work of a lifetime, which represents the sum of his entire career. Those lucky enough to assist him and accompany him on research trips in the East cannot fail to remember the red cover copy of his corpus, which he took everywhere in a constant effort to perfect the work. His burning passion for research drove his incessant visits to examine Urartian inscriptions still in situ regardless of the harshness of their sites of conservation - as well as those kept in museums.

Among the many places visited, that to which he is most attached is the Fortress of Van. On the top of that dramatically beautiful rock spur, he loved to read at dusk, to a lucky few, extracts from the 'History of the Armenians' by Movses Khorenatsi, especially the passages concerning the mythical foundation of the capital of Urartu by Queen Semiramis. While we certainly do not want to limit Mirjo's importance to the study of Urartu, given that he is also a scholar of primary importance in fields such as Hurritology and Hittitology, there is no doubt that his contribution to the civilization of Urartu is the most prominent, and that in which he invested most of his energy. We hope that this Festschrift presented to Mirjo by his friends, colleagues, collaborators and students, will serve as an appropriate tribute to this outstanding individual and scholar. Most of all, this book should be read as a sign of our gratitude for Mirjo's indefatigable enthusiasm in promoting Near Eastern studies, especially of Urartu.

We would like to thank all the contributors that have decided to participate to this work and the people that have helped us in the different stages of the process of realization, especially Kristine Martirosyan-Olshansky, Priscilla Vitolo, Nshan Tomas Kesecker, and Onofrio Gasparro. 


\section{Foreword}

The present volume represents an excellent opportunity to celebrate the career of an outstanding scholar and personal friend, active over the years in many fields of Oriental research.

Mirjo was one of the first researchers to embrace the aims of the new ISMEO re-founded in 2012 - and the Association itself has, since the beginning, welcomed the carrying on of Mirjo's scientific heritage, sponsoring many of the research lines he had been working for decades within the ICEVO framework.

We must remember Mirjo's creation of the Italian (now ISMEO) 'Urartu program', as part of which a series of investigations were conducted in the field, and linked to research activities that led over time to the publication of important reference works in Urartology. The main purpose of that project was to develop convergence between historical-philological and archaeological research work in the field; it reached its apex with the publication of the Corpus of Urartian Texts in five volumes, in which all known Urartian inscriptions are gathered together, translated and commented upon. As part of this research, important missions were started in Armenia and Iran.

ISMEO, since 2013, has taken charge of this rich scientific heritage, continuing archaeological and philological research into the Urartian civilization; in this context an extensive research program was launched and archaeological investigations have been started in the Southern Caucasus, in Armenia (since 2013) and in southern Georgia (since 2017), now incorporated into the ISMEO Archaeological Mission to South Caucasus. The main targets of these activities - developed in selected areas of particular relevance - include: (1) the investigation of protohistoric phases (Late Bronze/Early Iron Age), (2) close study of the birth of the Urartu state, its territorial organization, and the relations between the state and local communities (Middle Iron Age), (3) the cultural heritage left by the Urartu state after its decline in the territories that it occupied, in the 'Median' and Achaemenid periods (Late Iron Age). Precisely the question of the relations between Urartu and the Achaemenid world, in which Mirjo made important contributions, was the basis of a volume recently published by ISMEO. From the perspective of Achaemenid studies, Urartu's exact role is still debated and still presents many obscure points that only the progress of research will help to clarify.

All ISMEO members and friends are very glad to contribute with the present tribute to Mirjo's human qualities and scientific expertise.

Adriano Rossi, President, ISMEO

Rome, 17 June 2018 